\title{
An Opportunity to Build Legitimacy and Trust in Public Institutions in the Time of COVID-19
}

\section{Stuti Khemani}

Legitimacy in the time of COVID-19 can be understood as the ability of leaders to win compliance with new public health orders because people share a widespread belief that everyone is complying. This perspective-building on the logic of game theory, which can help explain strategic interactions among large numbers of people in a society or polity-yields a powerful insight: that governments in developing countries, as the first line of defense against a life-threatening disease, have received a windfall of legitimacy. On the one hand, this legitimacy windfall can be wasted-or worse, used to intensify divisive politics, grab power, and install government at the commanding heights of the economy and society, even after the pandemic recedes. On the other hand, for reform leaders and international development partners that are motivated to improve governance for economic development, the crisis presents opportunities to build trust in public institutions. In this task, international organizations have a comparative advantage precisely because they are not part of domestic political games. But this dynamic may require changing how donors typically approach corruption in developing countries (in the context of financial assistance to countries with institutional weaknesses that predate the crisis); it may also necessitate change in how reform leaders in countries use the advantage of external partners to exert pressure for reform. The availability and strategic communication of credible, nonideological, and nonpartisan knowledge could enable societies to change a vicious cycle of high levels of corruption/low levels of trust to a virtuous one of high levels of trust/low levels of corruption.

\section{Governance Concerns in the Time of the Coronavirus}

This Research \& Policy Brief examines the relationship between governance and the success of policies to manage the COVID-19 pandemic. As technical experts advise governments to institute non-pharmaceutical interventions (NPIs) such as social distancing and lock-downs, deliver health services, and protect and support markets and people, many urgent governance questions have emerged:

- Will people comply with public health regulations or NPIs?

- Will there be riots on the streets, or social chaos?

- Will governance challenges, such as corruption, get worse, if money is poured into countries with institutional weaknesses that predate the crisis?

- Will the global nature of the pandemic fuel politics of fear, enabling authoritarian leaders to close their borders, or worse, violate human rights?

- What should reform leaders and international agencies do to manage/forestall these concerns?

Given the unprecedented nature of this pandemic, this Brief offers answers to such governance questions by interpreting real-time events as these unfold during the COVID-19 crisis, using available research on governance and the political economy.

When countries and localities began to introduce social distancing measures, The Economist (2020a) ran a cover story on the "Politics of Pandemics," which implied that developing countries would not have the requisite trust in governments to comply with the lockdown. However, various events since then have suggested that despite low levels of trust, people in developing countries have complied with these measures.

Events during and after March 2020 present a stark contrast between the world's two largest democracies: the United States and India. The one with a wealthy economy, strong institutions of law and order, and high standards of living for most of its population (and thus ability to physically comply with social distancing measures in the comfort of people's homes) exhibited greater political confusion and disagreement, distrust of scientists, and citizen protests against the NPIs (Kleinfeld 2020; Tobin 2020; Peters 2020). Prior evidence from other policy areas has shown that political polarization along ideological lines fuels resistance to scientific evidence in the United States (Kahan, Jenkins-Smith, and Braman 2011; Kahan 2012). In contrast, in the one where poverty is widespread, and where many households lack basic life goods, there is far greater political and social unity over the need for NPIs (LiveMint 2020). In India, news outlets report that citizens are self-enforcing lockdowns-and even intensifying enforcement, keeping out migrant workers as they returned to their village homes (because they had lost their living space and jobs in the cities as a result of the lockdown) (Agrawal 2020).

Problems of social unrest, and law and order, predate the current crisis and may continue as the crisis adds to social and economic distress. For example, street violence has broken out in India as migrant workers return to their villages, only to be quarantined and unable to join their families (The Hindu 2020). But there have been few reports of newly widespread unrest and noncompliance with government orders. Across developing countries, there has been little evidence of renewed political protests or resistance to government measures to deal with the pandemic. Consistent with this real-time reading of news reports, ongoing research at the International Monetary Fund (IMF) is not finding significant statistical evidence that social unrest increases after epidemics (Spilimbergo 2020).

These real-time events can be interpreted using game theoretic approaches to understand strategic interactions among large numbers of people in a society or polity. Using game theory, this Brief shows how the coronavirus pandemic can be understood to have conferred a legitimacy windfall on governments in many developing countries. A legitimacy windfall carries the risk of being abused. Political leaders could try to use it to stoke the politics of fear and divisiveness and grab authoritarian power (The Economist 2020b). Campante et al. (2020), for instance, provide evidence that epidemics can be used by politicians to create fear of foreigners and pursue right-wing ideological policy agenda. Fast-tracked inflow of international development assistance could be captured by elites (Andersen, Johannesen, and Rijkers 2020). This Brief offers ideas for approaches to try to manage these risks and, instead, use the crisis as an opportunity to improve governance.

\section{Legitimacy in the Time of the Coronavirus}

Legitimacy can be defined in a game theory framework as the ability of leaders to win compliance with new laws or public orders because people share a widespread belief that everyone is complying. Recent work on law and economics reexamines the puzzle of why developing countries have laws on paper that are not effectively implemented (World Bank 2017). Instead of relying on explanations about weak 
governance, low capacity, and perverse political incentives, Basu (2018) argues that a conceptually clearer way of thinking about compliance with a new law is whether the new law changes beliefs about how others are behaving, and thus legitimizes compliance.

Using this perspective, the Brief offer a set of hypotheses about legitimacy, specifically in the context of non-pharmaceutical interventions (NPIs) to combat a pandemic. These hypotheses are based on the nature of the pandemic as a global, life-threatening shock against which governments are a first line of defense. Legitimacy depends upon beliefs - or focal points, in the language of game theory-about how others are behaving in political and bureaucratic institutions at the time of the shock.

- Legitimacy of new rules promulgated following a shock is not necessarily lower in developing countries, despite lower trust in government before the shock (as measured by perceptions of pervasive corruption).

- Low levels of trust in government before the shock can coexist with a high level of initial legitimacy to deal with the shock, because responses observed in other countries and the immediate risk to life create a focal point

- Legitimacy to deal with the shock could, however, be lower in countries with greater ideological polarization in political institutions. Divergence of beliefs between the polarized groups could affect calculations about whether others in their group are going to change their behavior.

- Legitimacy could also be lower where government bureaucracies are weaker (have lower autonomy to pursue a defined technical mandate), and are subject to greater political interference or are more dependent on politicians for funding and powers. Conversely, legitimacy is greater where government bureaucracies are empowered to function autonomously. Strong bureaucracies can circumvent the problem of political polarization, even where it exists, by providing focal points that are independent of politics, and presumably rooted in technical or scientific evidence and knowledge.

- Once political polarization and bureaucratic strength are controlled for, the difference in legitimacy, of new rules enacted to combat a shock, between democratic and authoritarian institutional regimes may be insignificant.

These hypotheses would not follow from other ways of analyzing legitimacy. For example, political science has analyzed legitimacy of governments as a whole by examining cases of protests and resistance against a government, rather than as an issue of compliance with new rules that have been enacted to combat a shock (Weatherford 1992). Another prominent analysis, the World Development Report on conflict (World Bank 2011), examined legitimacy as a bundle of complex attributes of government, politics, economies, and societies, which are far more likely to be present in developed rather than in developing countries.

The new hypotheses offered in this Brief appear to be relevant to understanding real-time events as these unfold in the context of the pandemic. The interpretation using the logic of game theory can be useful especially because, in these unprecedented times, there is little else available that is relevant to the pandemic. In developing countries, because of weaker markets and more interventionist states, initial legitimacy may be higher, even when measures of trust in government are low before the crisis, because governments are the dominant institutions through which societies address collective problems.

\section{Trust in the Time of the Coronavirus}

Trust has also been broken down in research to the fundamental elements of game theory-beliefs about how others are behaving in a particular game of life, society, or politics (Alesina and Giuliano 2015; Algan and Cahuc 2014). Within this large body of research, the 2 segment most relevant for understanding governance in the times of the coronavirus concerns corruption, viewed as the lack of trust in public institutions.

Where corruption is perceived to be high, it follows naturally that people lack trust in public institutions, believing that public resources are being stolen for private gain. Here, there is clear evidence that trust is lower in developing countries, given that people perceive corruption to be persistently widespread (World Bank 2016a; Chuah, Loayza, and Meyers 2020). Beliefs about corruption in the public sector yields an "equilibrium" - as the concept is used in game theory-of low trust and reliance on monitoring and punishment as the way to control corruption. However, if corruption is too widespread, controlling it by relying on monitoring and punishment can become untenable. Perpetrators of corruption can figure this out and thus become emboldened to continue engaging in corruption, knowing that formal rules for monitoring and punishment are difficult to enforce in practice (World Bank 2016a). That is, outcomes of high levels of corruption and low levels of trust go together.

When it comes to understanding the governance challenges of implementing COVID-19 health policies, a substantial body of literature is available that examines corruption specifically in the realm of public health service delivery in developing countries. This corruption largely takes the form of absenteeism and poor performance among doctors and nurses who are on the public payroll (World Bank 2004; Chaudhury et al. 2006; Das et al. 2016; Banerjee, Duflo, and Glennerster 2008). This research has found that doctors and nurses enjoy job security in the public sector and face few formal sanctions when they are absent. These findings have created space and funding for unprecedented volumes of research in developing countries using randomized control trials (RCTs) to estimate the impact of policy interventions to strengthen incentives of frontline public service providers to do their jobs. Given the status quo (equilibrium) of poor performance and weak incentives, it is perhaps not surprising that when incentives are credibly strengthened, such as when salaries of absent health workers are docked, workers' attendance goes up. However, researchers have found that the incentives that worked in the small-scale RCTs have not been sustained and scaled up into policy (Banerjee, Duflo, and Glennerster 2008; Dhaliwal and Hanna 2017).

The question relevant to governance policy is whether health workers should be provided steady wages and job security through the pandemic and beyond, to build a trustworthy cadre of community-embedded public health workers. Global health experts called for such a cadre after the Ebola outbreak in Africa, yet it did not materialize-and is not available for the COVID-19 pandemic. Should there be more significant or systemic shifts in management practices to give greater autonomy to and bestow trust on health workers to undertake tasks of a "public good" nature, such as fighting a pandemic?

Beyond the crisis of pandemics, public sector agencies are typically tasked with producing goods or delivering services that are precisely those for which incentives, as generated by markets, tend to fail. A classic problem is the task of educating the children of poor families, whose parents' capacity is limited by budget and credit constraints, in addition to any behavioral constraints imposed by poverty, lack of education, and social deprivation.

Economic theory argues that optimal contracts in complex organizations that are tasked with providing public goods could use low-powered incentives (steady wages, job security), and rely on recruitment of intrinsically motivated workers, as well as professional norms among peers to achieve high performance or productivity (see reviews of the literature in Dixit 2002; Khemani 2019). In essence, the logic of the theory-following from the nature of tasks that agents are required to perform in bureaucracies - calls for contract design that relies on greater trust in professional norms within bureaucracies. 


\section{Trust and Politics}

Despite perceptions of pervasive corruption, survey and other evidence indicates that people in developing countries believe in the role of government, and the role of elections in improving their lives and the economies. In this sense, "trust" in the role or potential of government is higher in developing than in developed countries.

Simple average of responses in public opinion surveys shows that people in developing countries are far more likely to agree with questions about the legitimate role of government in the economy, in service delivery, and for redistribution. For example, more than 40 percent of people in countries as different from one another as Brazil, Egypt, and India hold governments responsible "for ensuring that everybody is provided for" (World Values Survey), in contrast to less than 10 percent in Sweden and the United States.

People in the developing regions of the world believe in the potential of political institutions to improve their lives and their country's economy. In response to the World Value Survey, people in Sub-Saharan Africa, Latin America, and East Asia (the survey did not ask this question in China) respond almost unanimously that elections are "very" or "rather" important for making a difference in their lives and their countries' economies (World Bank 2016a). Despite personal experience with malpractices in elections, people nevertheless express belief in the potential of elections to improve outcomes. Consistent with beliefs about the potential of elections to improve their lives and their countries' economies, people in developing countries have high rates of political participation. In many developing countries, less educated and lower-income citizens tend to be more politically active than those with greater education and income, Pande (2011) estimates, drawing on household surveys across countries.

People in developing countries are not only engaging in politics as voters but also as contenders for leadership positions in local governments. Elections in local governments were instituted in a wave of decentralization across the world at the turn of the twenty-first century, lowering barriers to entry for leadership positions (World Bank 2016a). Microempirical research across diverse institutional contexts, such as Brazil, India, Indonesia, Kenya, Mexico, Pakistan, the Philippines, and Uganda, shows that local elections are highly contested, resulting in huge numbers of people engaging for local leadership positions.

High levels of political engagement as an indicator of trust in the potential of government can go hand in hand with low levels of trust in political leaders who wield power over government. An accumulating body of evidence shows that citizens in developing countries use elections to try to strengthen political incentives to respond to their demands, rather than relying on trust in leaders. Several pieces of evidence suggest this. First, developing countries are characterized by high levels of electoral volatility and turnover. Thus, incumbents face a disadvantage, contrary to the typical case of incumbency benefits in developed countries (Klašnja 2015; Uppal 2009). Second, there is evidence that elections can work to exact accountability, despite widespread malpractices such as vote-buying and violence (World Bank 2016a). For example, mayors in Brazilian municipalities subject to term limits engage in greater rent-seeking than those who are up for reelection, because of the disciplining effect of elections (Ferraz and Finan 2008, 2011). Third, when elections work less well in exacting accountability, it is precisely because trust is high-but is placed in the "wrong" things. For example, greater trust in social networks can enable vote-buying in elections, even with a secret ballot- and where there is greater vote-buying, public health services are worse (Khemani 2015). Where there is greater trust in ethnic networks, coethnics or specific political parties perform worse, such as by increasing rent-seeking or corruption in the use of public resources (Banerjee and Pande 2007). Where there is greater partisan or ideological attachment to political parties, those parties have weaker incentives to deliver services, even when those services are aligned with that party's ideology (Bardhan and Mookherjee 2010).

High-powered incentives in politics, or concomitantly, low trust that political leaders will perform well regardless of incentives, matter not only in electoral regimes but in other types of political systems. Besley and Kudamatsu (2008) examine variation across autocracies and find that where turnover of political leaders is high, economic performance is better. They interpret this correlation as arising from stronger incentives for performance within autocracies when political elites have the power to sanction leaders for poor performance.

The previous sections have broken down trust along different dimensions and argued that what matters for policy responses under the current crisis is trust in the potential of government, rather than trust in political leaders. Trust in the potential of government encourages people to be politically engaged, despite awareness of current or prevailing malpractices in politics. Whether this political engagement will be able to improve the effectiveness of policy responses to the crisis depends upon the quality of that engagement-whether the platforms of political competition are about economic performance and public service delivery or other criteria, such as identity and blind ideology (which resists evidence contrary to ideological beliefs). There is a risk that leaders can use the crisis to highlight attachments to identity, create divisions, and deflect attention away from performance.

Policy Implications: Leveraging Political Engagement along with the Focal Points of Change Created by the Pandemic to Improve Public Services

The pandemic has forcibly created a "focal point" -in the language of game theory-by endowing governments with high levels of legitimacy to implement public health regulations because governments are the first and necessary line of defense. Such a windfall endowment of legitimacy runs a risk of being abused by those political leaders who are motivated to expand their powers and divide society. Conversely, for reform leaders and international development partners that are motivated to improve governance for economic development, the crisis presents opportunities to build trust in public institutions.

International agencies may be tempted to try to bypass governments and deliver humanitarian aid through nongovernmental organizations because of concerns about elite capture of foreign aid (Andersen, Johannesen, and Rijkers 2020). This could prove to be shortsighted and miss another opportunity for improving governance in both the short and long term. Past research on aid-effectiveness, and recent research on the need for state capacity for economic development, suggests that attempts to bypass governments either fail or are insufficient (Knack 2001; Rajan and Subramanian 2007; Besley and Persson 2010).

The opportunity is to continue to use the focal points, along with the resources being allocated to public health and social protection, to target communication and messaging to build peer-to-peer professional norms and trust within government bureaucracies. Such peer-to-peer pressure and professional norms may improve the implementation of policies to combat the disease. More effective implementation translated into better health and social protection outcomes, which in turn may build trust in government bureaucracies extending beyond this crisis to strengthen public institutions going forward.

Several priorities and concrete steps are proposed to set in motion a virtuous cycle:

\section{Strengthening public sector personnel and management}

- Focus on frontline state personnel needed for war-scale implementation of public health measures, and distribution of 
supplies to ensure food, water, and hygienic living conditions among the poorest.

- Provide these personnel with steady wages, training, and equipment.

- Signal trust through management practices that motivate a sense of "mission" and encourage peer-to-peer monitoring (rather than hierarchical monitoring).

- Use local politics as the arena through which norms can shift in the public sector. Local politics is the space in which people communicate to form beliefs about how others are behaving in the public sector. In places where local politics revolve around vote buying and extending the patronage of secure jobs in government, the previous bullet is likely to be ineffective. This is the case because politics drives beliefs. If politics continues to revolve around patronage, people would rationally continue to believe that once they have secured a patronage job in the public sector, they do not need to perform.

\section{Better utilizing international agencies}

Apolitical international agencies, which are not part of the domestic political game, have a particular comparative advantage in helping to shift norms toward those conducive to economic development (World Bank 2016a, chapter 7, box 7.3). That comparative advantage is the credibility of messages about the performance of public policies being pursued by governments. The source of the credibility is scientific and technical expertise to gather and examine data, and build messages based on hard evidence. This credibility too may be imperfect, in an age characterized by populist distrust of experts. But in developing countries where political leaders are not trusted, evidence-based messages about the performance of public policies sourced from international professionals may help improve the quality of contestation in local political arenas, shifting it away from patronage and rent-seeking and toward performance in serving the public good. Such messaging might counter "fake news" and help undermine the use of divisive identity and fear in politics.

\section{Strengthening local media}

The sponsorship of local media in delivering these messages might also strengthen local media markets. An extensive policy research report on governance (World Bank 2016a) found that the presence of local media markets, such as locally headquartered radio stations in the continent of Africa, is one of the most robust correlates of the control of corruption. In contrast, measures of other governance policy areas that are popular with international organizations, such as presence of civil society organizations or freedom of information laws, are not found to be robustly correlated with the control of corruption. The report recommends focusing grants to civil society organizations to improve contestability in local political and media markets, rather than to support social accountability mechanisms that bypass politics. These suggestions may be particularly relevant in the time of COVID-19 because citizens may not want to shoulder the additional burden of monitoring local service delivery. For example, a successful case of community mobilization showed that success depends upon citizens' effort at collective action. Banerjee et al (2010) find dramatic improvements in education outcomes after youth in villages mobilized remedial reading classes among children who were not learning in school. However, the social accountability campaign had no impact on accountability and performance of teachers on the public payroll. Addressing political incentives and professional norms in bureaucracies is needed so that citizens can be better served in this hour of need, rather than having to mobilize themselves at every front to improve service delivery.

\section{Using technology to deliver public services and benefits}

Technology, where feasible, can deliver benefits directly to citizens, reducing reliance on agents (and hence opportunities for corruption 4 or inefficiencies), such as by establishing secure payment infrastructure and funds flow for delivering cash transfers period i.e. cash transfers.

There has been considerable enthusiasm around using technology to manage funds flows, cut-out middlemen, and improve monitoring. Research has found that technology can indeed be used to reduce leakages in one area of public policy-making welfare payments to protect the poor and vulnerable (Muralidharan, Niehaus, and Sukhtankar, 2016; Banerjee et al. Forthcoming). However, a World Development Report assessing the role of technology concluded that while it has useful applications to improve governance, the fundamental question remains whether political leaders have the incentives to take up appropriate technologies and not abuse them by infringing on privacy and civic freedoms (World Bank 2016b).

\section{Leveraging development assistance}

The looming governance question in international development is: Will the governments of developing countries squander the financial assistance that citizens of developed countries might provide them? International agencies are worried about whether new scandals will erupt as they try to fast-track projects to help the poor and vulnerable in this hour of humanitarian need. It was only a few months ago that evidence of corruption in aid-dependent countries embarrassed these agencies (Jones 2020). How should development agencies square this circle of giving more money, more quickly with the concerns of corruption and misuse?

The foregoing analysis yields the following answers to these questions. Providing more and fast-tracked financing could be accomplished by providing financial assistance to countries largely in the form of general budget support, despite the concerns about corruption. To address corruption, and governance more generally, knowledge products have the potential of being leveraged more effectively (Devarajan and Khemani 2018). For example, budget support could be more strongly conditioned on freedom to gather data, build evidence about how governments and public policies are performing, and on communicating this evidence using a variety of local media. Projects could be used as needed to test a new type of policy, to generate knowledge about what governments can do better to deliver public health, support markets, and protect society. In this view, projects serve more as a knowledge product, and leave room to learn from both success and failure, while budget support is the primary means of disbursing financing. This enables "unbundling" financing from knowledge, so that each instrument is better able to achieve its objectives, as argued in Devarajan and Khemani (2018).

Evidence of corruption may emerge in this process, as in the "cashgate" scandals where donor-supported integrated financial management systems (IFMS) exposed fraudulent transactions, but ultimately could not prevent those transactions from happening (Blas 2013). The ex ante conditions of budget support would need to be explicit about how evidence of corruption could trigger the cessation of international support. Determining the size of budget support in relation to the size of the economy, its macroeconomic fundamentals, and costing of basic public service needs, is also crucial. This would place the burden of controlling corruption on the leaders and people whose countries it is; this has been referred to as "putting countries in the driver's seat" (Jerve 2002). The weight of research on aid-effectiveness and state capacity can be leveraged to support this approach rather than donor oversight and control (Knack 2001; Rajan and Subramanian 2007; Besley and Persson 2010). Such a strategy would free international agencies to focus on generating the global public good of knowledge, and tailoring it for practical application to country contexts, using projects as needed for this learning purpose rather than as principal vehicles for disbursing financial assistance.

Governance practices are specific to each policy area, shaped by the nature of the tasks government agents are required to perform in pursuing that policy. For instance, in the area of social protection, 
direct transfers to household bank accounts have been shown to work, and provide an example where technology can be used to reduce corruption (Muralidharan, Niehaus, and Sukhtankar, 2016). However, for policies in health and education, no country in the world has succeeded without relying on building trust and professional norms among human resource personnel such as doctors, nurses, public health workers, and teachers. How governance practices are performing, and whether alternatives exist that would improve outcomes in any policy area, is also part of the knowledge generation that international agencies could intensify. Academics have pointed to the need for more research and learning on governance practices in policy areas such as health, education, social protection, and regulation. In its absence, researchers are hard-pressed to give concrete policy advice to leaders who want to control corruption (Olken and Pande 2012).

\section{Using communication strategically to shift norms}

Examining legitimacy and trust as key concepts of governance using game theory shows how communication is pivotal for moving from one "equilibrium" to another by changing what people believe about how others are behaving. Reform leaders in countries can use external partners precisely because they operate outside the domestic political game for the kind of strategic communication needed to shift from a vicious cycle of high levels of corruption/low levels of trust to a virtuous one of low levels of corruption/high levels of trust.

Credible, nonideological, and nonpartisan knowledge is at a premium, perhaps more than ever before. The generation of such knowledge and its strategic communication, taking local political institutions into account, could work by countering the spread of "fake news" and improving contestability of local political markets on platforms of the common good.

International organizations have a comparative advantage in leveraging technical evidence and apolitical, nonpartisan reputations to communicate messages for peer-to-peer monitoring and professional norms in bureaucracies. Messages and communication could enable citizens to be more critical of identity politics and more equipped to hold political leaders accountable for serving the common interest.

In sum: Legitimacy for public health regulation has been by necessity thrust upon governments because of the pandemic. This creates focal points to shift expectations in society about the role of government bureaucracies. These focal points could be used to build trust in bureaucracies and the professionalism of public service providers. International research and policy could move away from relying on high-powered incentives and fueling distrust by asking citizens to directly monitor public service providers. Instead, international organizations have a comparative advantage in leveraging technical evidence and apolitical, nonpartisan reputations to communicate messages for peer-to-peer monitoring and professional norms in bureaucracies. Where distrust has a constructive role to play-in politics - messages and communication could enable citizens to be more critical of identity politics and more equipped to hold political leaders accountable for serving the common interest.

\section{References}

Agrawal, P. 2020. "Covid-19 Lockdown: Bihar Migrants Who Fled Cities Face Ostracism at Home." IndiaSpend.com, April

https://scroll.in/article/958010/covid-19-lockdown-bihar-migrants-who-fled-cities-face-ostracism-at-

Alesina, A., and P. Giuliano. 2015. "Culture and Institutions." Journal of Economic Literature 53 (4): 898-944. Algan, Y., and P. Cahuc. 2014. "Trust, Growth, and Well-being: New Evidence and Policy Implications." In Handbook of Economic Growth, edited by P. Aghion and S. Durlauf, Vol. 2, Chapter 2, 49-120. Elsevier.

Andersen, J. J., N. Johannesen, and B. Rijkers. 2020. "Elite Capture of Foreign Aid: Evidence from Offshore Bank Accounts." Policy Research Working Paper 9150, World Bank, Washington, DC.

Banerjee, A. V., E. Duflo, C. Imbens, S. Mathew, and R. Pande. Forthcoming. "E-governance, Accountability, and Leakage in Public Programs: Experimental Evidence from a Financial Management Reform in India." American Economic Journal: Applied Economics.

Banerjee, A.V., R. Banerji, E. Duflo, R. Glennerster, and S. Khemani. 2010. "Pitfalls of participatory programs: Evidence from a randomized evaluation in education in India." American Economic Journal: Economic Policy, 2(1), pp.1-30.

Banerjee, A.V., E. Duflo, and R. Glennerster. 2008. "Putting a band-aid on a corpse: incentives for nurses in the Indian public health care system." Journal of the European Economic Association, 6(2-3), pp.487-500

Banerjee, A., and R. Pande. 2007. "Parochial Politics: Ethnic Preferences and Politician Corruption." Working .

Bardhan, P., and D. Mookherjee. 2010. "Determinants of Redistributive Politics: An Empirical Analysis of Land Reforms in West Bengal, India." American Economic Review 100 (4): 1572-1600.

Basu, K. 2018. The Republic of Beliefs: A New Approach to Law and Economics. Princeton, NJ: Princeton University Press.

Besley, T. and T. Persson. 2010. "State capacity, conflict, and development." Econometrica, 78(1), pp.1-34.

Besley, T., and M. Kudamatsu. 2008. "Making Autocracy Work." In Institutions and Economic Performance, edited by E. Helpman. Cambridge, MA: Harvard University Press.

Blas, J. 2013. "Malawi 'Cash-Gate' Corruption Scandal Unfolds Like a Thriller." Financial Times, November 19. Campante, F., E. Depteris-Chauvin, and R. Durante. 2020. "The Virus of Fear: The Political Impact of Ebola

Chaudhury, N., J. Hammer, M. Kremer, K. Muralidharan, and F. H. Rogers. 2006. "Missing in Action: Teache and Health Worker Absence in Developing Countries." Journal of Economic Perspectives 20 (1)

Chuah, L. L., N. V. Loayza, and C. B. Myers. 2020. "The Fight against Corruption: Taming Tigers and Swatting Flies." Research \& Policy Brief No. 27, World Bank Group, Washington, DC

Das, J., A. Holla, A. Mohpal, and K. Muralidharan. 2016. "Quality and Accountability in Health Care Delivery: Audit-Study Evidence from Primary Care in India. American Economic Review

Devarajan, S. and Khemani, S., 2018. "If politics is the problem, how can external actors be part of the solution?" In K. Basu and T. Cordella (Eds.) Institutions, Governance and the Control of Corruption (pp.

Dhaliwal, I., and R. Hanna. 2017. "The Devil Is in the Details: The Successes and Limitations of Bureaucratic Reform in India." Journal of Development Economics 124: 1-2

Dixit, A. 2002. "Incentives and Organizations in the Public Sector: An Interpretative Review." Journal of Human Resources 37 (4): 696-727.

Easterly, W., R. Levine, and D. Roodman. 2004. "Aid, policies, and growth: comment." American economic review, 94(3), pp.774-780.

Economist, The 2020a. "The Politics of Pandemics." March 12 https://www.economist.com/leaders/2020/03/12/the-politics-of-pandemics.

-. 2020b. "A Pandemic of Power Grabs: Autocrats See Opportunity in Disaster." April 23. https://www.economist.com/leaders/2020/04/23/autocrats-see-opportunity-in-disaste

Ferraz, C., and F. Finan. 2008, "Exposing Corrupt Politicians: The Effects of Brazil's Publicly Released Audits on Electoral Outcomes." The Quarterly Journal of Economics 123 (2): 703-45.

--. 2011. "Electoral Accountability and Corruption: Evidence from the Audits of Local Governments." American Economic Review 101 (4): 1274-1311.

Hindu, The. 2020. "National Cornonavirus Lockdown: Migrant Workers Not Welcome Back Home in Bihar." March 29.

https://www.thehindu.com/news/national/coronavirus-lockdown-migrant-workers-not-welcome-backome-in-bihar/article31200962.ece.

Jerve, A. M. 2002. "Ownership and Partnership: Does the New Rhetoric Solve the Incentive Problems in Aid?" Forum for Development Studies 29 (2): 389-407.

Jones, C. 2020. "The World Bank Paper at the Centre of a Controversy." Financial Times, February 18. https://ftalphaville.ft.com/2020/02/17/1581940412000/The-World-Bank-paper-at-the-centre-of-acontroversy/.

Kahan, D. M. 2012. "Ideology, Motivated Reasoning, and Cognitive Reflection: An Experimental Study." Judgment and Decision Making 8 (4): 407-24.

Kahan, D. M., H. Jenkins-Smith, and D. Braman. 2011. "Cultural Cognition of Scientific Consensus." Journal of Risk Research 14 (2): 147-74. Khemani, S. 2015. "Buying Votes versus Supplying Public Services: Political Incentives to Under-Invest in
pro-Poor Policies." Journal of Development Economics 117 (C): $84-93$.

Khemani, S. 2019. "What Is State Capacity?" Policy Research Working Paper 8734, World Bank, Washington, DC. Klašnja, M. 2015. "Corruption and the Incumbency Disadvantage: Theory and evidence." The Journal of Politics 77 (4): 928-42.

Kleinfeld, R. 2020. "Do Authoritarian or Democratic Countries Handle Pandemics Better?" Commentary March 31 2020, Carnegie Endowment for International Peace.

Knack, S. 2001. "Aid Dependence and the Quality of Governance: Cross-country Empirical Tests." Southern Economic Journal, 68(2): 310-329.

LiveMint. 2020. "West Bengal Extends Lockdown till 30 April amid Covid-19 Outbreak," April 11 https://www.livemint.com/news/india/west-bengal-extends-lockdown-till-30-april-amid-covid-19outbreak-11586611855306.htm

Muralidharan, Niehaus, and Sukhtankar. 2016.

Olken, B. A. and R. Pande. 2012. "Corruption in developing countries." Annual Review of Economics, 4(1), pp.479-509.

Pande, R. 2011. "Can informed voters enforce better governance? Experiments in low-income .

Peters, J. 2020. "Alarm, Denial, Blame: The Pro-Trump Media's Coronavirus Distortion." The New York Times, April 1,2020

Rajan, R. and A. Subramanian. 2007. "Does aid affect governance?." American Economic Review, 97(2), pp.322-327.

Spilimbergo, Antonia. 2020. "Discussion: 'Legitimacy and Trust: Strengthening Government Institutions in the times of the Coronavirus' by Stuti Khemani, and 'The Virus of Fear: The Political Impact of Ebola in the U.S.,' by Filipe Campante, Emilio Depetris-Chauvin, and Ruben Durante. http://pubdocs.worldbank.org/en/507111587074031803/Discussion-Antonio-Spilimbergo-pol-ec-
Covid.pdf

Tobin, J. 2020. "Conservative Pundits Weren't the Only Ones to Get the Pandemic Wrong." National Review, April 3,2020 https://www.nationalreview.com/2020/04/coronavirus-pandemic-conservative-and-liberal-punditsunderestimated-threat/.

Uppal, Y. 2009. "The Disadvantaged Incumbents: Estimating Incumbency Effects in Indian State Legislatures." Public Choice 138 (1-2): 9-27.

Weatherford, M.S. 1992. "Measuring political legitimacy." American Political Science Review, 86(1), pp.149-166.

World Bank. 2004. World Development Report 2004. Making Services Work for Poor People. Washington, DC: World Bank

2011. World Development Report 2011. Conflict, Security, and Development. Washington, DC: World Bank.

2016a. Development Research Group Policy Research Report. Making Politics Work for Development: Harnessing Transparency and Citizen Engagement. Washington, DC: World Bank. 2016b. World Development Report 2016: Digital Dividends. Washington, DC: World Bank. 2017. World Development Report 2017: Governance and the Law. Washington, DC: World Bank. 